\title{
Legal Standards of Economic Regulation of Environmental Protection and Nature Resource Management
}

\author{
Samat Jumagalievich Smoilov*, Pernebek Kurashovich Umirzakov, Bakyt Akilbaevna Zhussipova, \\ Arman Tleuberdievna Kaltayeva and Aliya Kiaysbekovna Jandarbekova \\ L. N. Gumilyov National University, Almaty, Kazakhstan; monblan.pro@yandex.ru
}

\begin{abstract}
The article examines the theoretical and methodological ideas of interpretation of the concept of the place of norms related to the mechanism of economic regulation of environmental protection and natural resource management in the legal system under the conditions of transition of the Republic of Kazakhstan to a green economy. The article shows the basic concepts and categories, the structure and the system of the place of norms related to the mechanism of economic regulation of environmental protection and natural resource management in the legal system, presents the genesis of formation of the place of norms related the mechanism of economic regulation of environmental protection and natural resource management in the legal system, the concept of the place of norms related to the mechanism of economic regulation of environmental protection and natural resource management in the legal system, performs a legal analysis of the place of norms related to the mechanism of economic regulation of environmental protection and natural resource management in the legal system, examines the legal problems of the place of norms related to the mechanism of economic regulation of environmental protection and natural resource management in the legal system. It also states the basic theoretical principles and recommendations for improving the current legislation of the Republic of Kazakhstan and its practical application.
\end{abstract}

Keywords: Ecological and Legal Norms, Economic Mechanisms, Economic Regulation, Environment, Environmental Code, Environmental Functions, Environmental Insurance, Environmental Law, Environmental Regulations, Environmental Rights, Green Economy, Natural Resource Management

\section{Introduction}

During the period of development of independent Kazakhstan, an extensive legislative framework has been formed in the field of environmental protection and rational use of natural resources, the crown of which is the Environmental Code of the Republic of Kazakhstan dated January 9, 2007.

Along with that, the existing array of environmental regulations still does not provide an adequate level of legal support of the economic regulation of the environmental protection in the Republic of Kazakhstan.
The regulations in this area are fragmented, contradict each other, do not comply with the Constitution of the Republic of Kazakhstan; many regulations are a reflection of lobbied private interests of certain groups of the population; not all legal acts are socially oriented to protect the environmental rights and lawful interests of individuals and legal entities.

The mechanism of economic regulation of environmental protection and natural resource management formed to date does not represent a unified picture; it consists of separate and not always inter-related elements.

\footnotetext{
* Author for correspondence
} 
It is necessary to study the main reasons of the ineffectiveness of this mechanism, develop recommendations and proposals to create an optimal system of legal support of all of its elements to ensure its successful functioning.

The above mentioned shows that the problems of the legal support of the mechanism of economic regulation of environmental protection and natural resource management in the Republic of Kazakhstan claim attention on the part of science, which should theoretically comprehend the role of the state and law in the process of formation of a conceptually new model of environmental policy (the transition of the Republic of Kazakhstan to a green economy) and suggest legal instruments for its effective implementation in the current conditions. The transition of the Republic of Kazakhstan to a green economy requires a substantiation of the new priorities, a review of the conceptual provisions, aims and objectives of ecological and legal science.

The selected topic is at the crossroads of economic and legal sciences; therefore, a series of fundamental studies was conducted by legal scholars.

The studies are presented by legal scholars examining legal aspects of the individual structural elements of the norms related to the mechanism of economic regulation of environmental protection and natural resource management, in particular the place and importance of the norms related to the mechanism of economic regulation of environmental protection and natural resource management. These are: "General Theory of Law and State"1; "Constitutional Law of the Republic of Kazakhstan"; "General Theory of Law"3.

A number of studies are devoted to the content of the norms related to the mechanism of economic regulation of environmental protection and natural resource management: "Theory of State and Law", "The Theory of State and Law: Study guide"5; "Legal Regulation of Protection and Use of Transboundary Natural Objects (through the Example of the Republic of Kazakhstan)"6.

Only one comprehensive monographic study has been devoted exclusively to the mechanism and structure of economic regulation of the norms related to the economic regulation of environmental protection and natural resource management: the work by T. V. Petrova on the topic "Problems of Legal Support of the Economic Mechanism of Environmental Protection"'.

This issue has not been paid due attention in the Republic of Kazakhstan. Kazakhstani scientists have considered only individual aspects of this issue, relating to natural resource payments, environmental insurance, financial control over the expenditure of funds allocated for environmental protection.

However, the issues, which, in our opinion, are of a fundamental interest, were left beyond the pale of the research. These include: development of a definition of the concept of the "mechanism of economic regulation of environmental protection and natural resource management"; determination of the base structural elements of this mechanism; identification of the inefficiency issues of this mechanism.

The main purpose of this work is a comprehensive study of the legal issues of finding the place of norms related to the mechanism of economic regulation of environmental protection and natural resource management in the legal system, the structure of the norms related to the mechanism of economic regulation of environmental protection and natural resource management in the legal system by analyzing relevant regulations and enforcement activities of the state in the field of implementation of the ecological function, interaction of state authorities with specially authorized bodies in the field of environmental protection.

In this connection, the following tasks were set:

- To explore the history of formation and development of the norms related to the mechanism of economic regulation of environmental protection and natural resource management in the Republic of Kazakhstan;

- To conduct a legal analysis of the norms related to the mechanism of economic regulation of environmental protection and natural resource management in the Republic of Kazakhstan;

- To determine the place of the norms related to the mechanism of economic regulation of environmental protection and natural resource management in the Republic of Kazakhstan in the system of environmental law;

- To identify the problems of improving the norms related to the mechanism of economic regulation of environmental protection and natural resource management in the Republic of Kazakhstan;

- To analyze the legal sources of the norms related to the mechanism of economic regulation of environmental protection and natural resource management in the Republic of Kazakhstan.

This problem requires a fairly deep and thorough legal analysis, which conditions the necessity of theoretical developments and formation of proposals 
and recommendations for the development of the most accurate definition of the place of the norms related to the mechanism of economic regulation of environmental protection and natural resource management in the Republic of Kazakhstan.

Environmental regulations also are obligatory for everyone (i.e. these the rules of conduct must be strictly observed by all entities using natural resources), formally defined (as they are prescribed in regulatory documents adopted in the order established by the state (Environmental Code of the Republic of Kazakhstan, the Land, Water, and Forest Codes of the Republic of Kazakhstan, etc., or in contracts for natural resources), interconnected with the state (as they express the will of the state, its interest in the environment, favorable for the life and health of citizens and are secured by the coercive power of the state), permissively-binding (i.e. the environmental obligation corresponds to the subjective environmental law).

The environmental regulations "have a number of specific features determined by the special role of public relations that they are to regulate. Firstly, the environmental regulations are of comprehensive nature, as they are provided not only in special environmental and natural resource acts, but also in the sources of constitutional, civil, criminal, labor and other branches of law of the Republic of Kazakhstan. Secondly, they are determined not only by the socio-economic conditions, but also by nature-related factors. Thirdly, based on the fact that certain natural objects are non-renewable, the state is required to establish special ecological and legal norms aimed at protection and management of the natural environment.

\section{Research Methods}

At the present stage of development of the environmental law and environmental legislation of the Republic of Kazakhstan, the norms of economic regulation of environmental protection and nature resource management represent an independent legal institution, which may be called the "mechanism of economic regulation of environmental protection and nature resource management". This legal institution is definitely included in the General part of the environmental law that comes out of its importance for the main institutions of the Special part of the environmental law.
In the theory of the environmental law, the concept of "expenditures for environmental protection" has not yet been clarified; therefore, we propose the following definition: they are the socially necessary expenditures to maintain the quality of the environment, to provide the functioning of the environmental infrastructure, to restore natural resources.

In the study, we used scientific principles and methods based on the requirements of an objective and comprehensive analysis of the processes and phenomena of social development and the functioning of the system of financing the system of costs of environmental protection and its legal bases.

We used the following methods in the research: the principle of systematic approach; the structural, functional, historical-legal, logical principles, the principle of statistical research, of a comparative legal analysis, and of forecasting.

The method of functional approach was used for the study of the problem of determining the place of norms related to the mechanism of economic regulation of environmental protection and natural resource management in the Republic of Kazakhstan in the system of the environmental law. In particular, two groups of methods were used - methods of positive and negative motivation.

Methods of positive motivation are measures that could interest the users of natural resources, incentives for users of natural resources who conduct the policy of preserving the natural environment. These include funding environmental protection measures, releasing from payment to the budget, granting preferential loans, awarding bonuses based on the results of environmental activities, leaving part of the profit from the sale of products made of waste products at the disposal of companies and transferring it to the funds of economic incentives.

The Environmental Code of the Republic of Kazakhstan lists only funding of environmental protection measures and economic incentives for environmental protection of all the above-mentioned items. At the same time, funding measures for environmental protection not at the expense of natural resource users will be considered as a positive method, while economic incentives for environmental protection will be considered as a positive method only if they bear property and other benefits for nature resource users. 
Methods of negative motivation are methods aimed at regulating the behavior of users of natural resources in the best interests of environmental protection and rational natural resource management by depriving them of property benefits. These include fees for emissions; fees for the use of certain types of natural resources; penalties, compensation of damages.

The study of the state of environmental safety of enterprises was conducted by the observation method. For example, we analyzed the volume of gross output of various sectors. The output of the agriculture, forestry and fisheries in Kazakhstan in 2011 amounted to 5\% of GDP, the industrial production of the mining industry reached $18.2 \%$; in 2012, the volume of gross output of agriculture, forestry and fisheries in Kazakhstan amounted to $4.3 \%$ of GDP, and the industrial production of the mining industry reached $17.5 \%$. In 2013 , these values equaled to $4.5 \%$ and $16.5 \%$, respectively.

The analysis of information on the environmental situation, environmental protection funding (emissions, pollution, cost of environmental protection) was provided by the statistical method. Thus, the analysis of the costs of environmental protection in the Republic of Kazakhstan showed that in 2011 the cost of environmental protection of enterprises and organizations amounted to 185.6 billion tenge.

In the structure of expenses, the protection of air and climate account for, the management of waste treatment - $28.8 \%$, the protection of water sources from pollution by sewage $-22.5 \%$, the protection and recovery of soil, groundwater and surface water sources - $17.9 \%$.

We also used the method of comparative legal analysis. For example, the expenditures for environmental protection are as follows: in $2011-0.67 \%$; in $2012-0.64 \%$; in $2013-0.64 \%$ of GDP.

\section{Results}

The study of the issue of determining the place of norms related to the mechanism of economic regulation of environmental protection and natural resource management in the legal system allowed obtaining the following results:

- An analysis of the legislation of the Republic of Kazakhstan allowed to come to the conclusion that the methods of economic regulation represented in it included mainly negative motivation techniques, which are sufficiently contained in the legislation. Con- cerning the methods of positive motivation, they are practically absent from the Environmental Code of the Republic of Kazakhstan. Therefore, our proposal will be to complement the environmental, banking and tax legislation of the Republic of Kazakhstan with norms related to the methods of economic regulation based on the positive motivation.

- At the present stage of development of the environmental law and environmental legislation of the Republic of Kazakhstan, the norms of economic regulation of environmental protection and nature resource management constitute an independent legal institution, which may be called "economic regulation mechanism of environmental protection and nature resource". This legal institution is definitely included in the General part of the environmental law that comes out of its significance for the main institutions of the Special Part of the environmental law.

- The structure of the mechanism of economic regulation of environmental protection and nature resource management consists of the following elements: 1 . Entities providing economic incentives for natural resource users; 2 . The system of legal norms supporting the activities of these entities. 3 . The regulatory process of behavior of nature resource users by these entities.

- The content of the mechanism of economic regulation of environmental protection and natural resources management consists of the means and methods used by the entities providing economic incentives for natural resources, based on the distribution and redistribution of wealth and interests.

As for the determination of the place of norms related to the mechanism of economic regulation of environmental protection and nature resource management in the legal system, we came to the following conclusions:

- The norms related to the mechanism of economic regulation of environmental protection and nature resource management definitely should be included in the General part of the environmental law, as they relate to any type of use and protection of natural objects in any area of human activity.

- The mechanism of environmental protection and nature resource management consists of the following types - public and legal, social, economic, ideological. We believe that this list should be included as a separate article in the Environmental Code of the Republic of Kazakhstan.

- The norms should comprise: 1 . The scientific issues related to the subject, system and methods of the en- 
vironmental law, its relationship with other branches, the concept, structure and place of the environmental legislation in the legal system, the hierarchy of law sources, the systematization and codification of law; 2. The issues concerning the concepts and principles of environmental management, the functions, status, competence, rights and responsibilities of the supervisory bodies and persons; 3 . Description of the main instruments for environmental protection, reflecting the legal administrative or legal economic mechanisms of the environmental law, which include: the environmental impact assessment, eco-certification, a system of registration and approval (licensing), declarations and statements of operations and condition, as well as environmental payments (taxes and charges), auditing, insurance, etc. 4 . The problem of legal liability for environmental offenses.

\section{Discussion}

Representatives of the theory of state and law identify several signs of a legal institution.

For example, according to V. V. Lazarev and other scientists, "a legal institution represents a separate unit of a branch of law, which is characterized by: 1 . Homogeneity of the actual content - each institution is designed for regulation of an independent, relatively isolated group of relations or specific actions or deeds of people; 2. Legal unity of the norms. The norms included in a legal institution form a single body, are expressed in general terms, legal principles, specific legal concepts, which creates a special legal regime inherent in this type of relationship; 3. Regulatory isolation, i.e. isolation of norms that form a legal institution in chapters, sections, parts, and other structural units of the law or other legal act. 4. Completeness of the regulated relations ${ }^{8}$.

Environmental scientists also distinguish the characteristic attributes of a legal institution. For example, Gavrilova identified three attributes: 1. Independent regulatory impact of the institution on a certain area of relations; 2 . Actual and legal uniformity; 3. Separation of norms forming a legal institution in chapters, sections, parts and other structural units of laws and other regulations ${ }^{6}$.

We need to consider whether the totality of norms related to the mechanism of economic regulation of environmental protection and natural resources management meets all the attributes of a legal institution.

Firstly, these norms feature the uniformity of the actual content. The norms of economic regulation of environmental protection and nature resource management regulate a certain narrow circle of homogeneous social relations - relations within the economic regulation of environmental protection and natural resources management.

Secondly, the norms related to the mechanism of economic regulation of environmental protection and nature resource management are legally homogeneous, as well.

The norms under consideration are expressed in general terms, specific legal principles, specific legal concepts that create a special legal regime inherent in this type of relationship.

Moreover, up to date, the norms of economic regulation of environmental protection and nature resource management are legislatively isolated, i.e. the norms constituting the legal institution are isolated in chapters, sections, parts, and other structural parts of the law or another legal act. For example, the Environmental Code of the Republic of Kazakhstan contains Section 3 "Economic Regulation of Environmental Protection and Natural Resources Management”.

Currently, however, such attribute as fullness of regulated relations is missing, which determined to the choice of the topic of our research.

Thus, the norms related to the mechanism of economic regulation of environmental protection and nature resource management represent an independent institution of the branch of environmental law at this stage of development of the environmental legislation.

"A branch of law... is a relatively independent, properly ordered set of interrelated legal norms aimed at regulating a qualitatively homogeneous sphere (kind) of social relations, forming a specific subject of legal regulation"6.

There is no need to consider in detail the environmental law concept and substantiate its independence in the system of law in our study. This issue has repeatedly been discussed in the theory of environmental law.

The next issue to be considered in our study is the determination of the place of norms related to the mechanism of economic regulation of environmental protection and nature resource management in the environmental law. 
The system of environmental law includes General, Special and Specific parts. The norms under study are included in the General part of the environmental law. This is due to the inclusion of the corresponding section in the Environmental Code of the Republic of Kazakhstan and in the system of environmental law as an academic discipline.

The norms related to the mechanism of economic regulation of environmental protection and nature resource management definitely should be included in the General part of the environmental law, as they relate to any type of use and protection of natural objects, to any area of human activity. According to S. T. Kulteleev, "Institutions of the general part of the environmental law include the institutions that are generally important for the whole system of the branch. These legal institutions have a decisive influence in the formation of the content and structure of the institutions of the special part ${ }^{9}$.

Scientists have distinguished such a legal institution as the "mechanism of economic regulation of environmental protection and natural resources management" a long time ago. For example, D. L. Baideldinov distinguished the institution of the "legal principles of the economic mechanism of environmental protection and nature resource management" in the General part of the environmental law $^{10}$.

A similar independent legal institution is distinguished by G. E. Bystrov, the author of "Environmental Law", in the General part of the environmental law - "economic regulation of environmental protection and nature resource use";"11 E. Iu. Ismailova -"legal economic mechanism of natural resource management and environmental protection"; ${ }^{12}$ I. S. Kovaleva - "economic mechanism of environmental protection"; ${ }^{13}$ B. V. Erofeev - "ratio of economy and ecology: the legal aspect"; ${ }^{14}$ and many others.

But not all authors identify this legal institution. For example, S. T. Kulteleev did not have the considered institution in the General part ${ }^{9}$.

Some authors distinguish the mechanism of economic regulation of environmental protection and nature resource management as a subinstitution. For example, S. D. Bekisheva included the institution in the larger institution of the "mechanism of environmental protection and nature resource management", which consists of the following types - legal public, social, economic and ideological ${ }^{15}$.

According to O. L. Dubovik, the General part contains:
1. Scientific issues concerning the subject, the system and methods of the environmental law, its correlation with other branches, the concept, structure and place of the environmental law in the legal system, the hierarchy of the law sources, its systematization and codification; 2. The issues concerning the concepts and principles of environmental management, the functions, status, competence, rights and responsibilities of the supervisory bodies and persons; 3 . The characteristic of the main instruments for environmental protection, reflecting the legal administrative or legal economic mechanism of the environmental law, which include: environmental impact assessment, eco-certification, the system of registration and approval (licensing), declarations and statements of operations and condition, as well as environmental payments (taxes and charges), auditing, insurance, etc.; 4. The issues of legal liability for environmental offenses ${ }^{16}$.

As we can see, the legal-economic mechanism of the environmental law as represented by O. L. Dubovik is a subinstitution of a larger institution.

Another interesting approach was proposed by V. V. Petrov. He pointed out that "in its current form, the environmental law system includes five environmental parts.

The first one is the subject, sources and objects of the environmental law. This part considers the concept of interaction between the society and the nature, the forms of the environmental law, its sources, facilities, property and natural resources management.

The second part is the mechanism of the environmental law, including the concept of the mechanism of environmental protection and its elements: environmental management with its bodies and functions, valuation of the natural environment, the economic mechanism of natural environment, environmental impact assessment and environmental monitoring.

The third one considers the legal protection of the environment in the economy. The objects of attention here are: the mechanism of environmental protection in economic activities, the protection of the natural environment in the industrial, power-generating and other sectors of the economy, in cities, suburban and recreational areas, and protected areas.

The fourth part is the environmental responsibility. This refers to the grounds and types of this responsibility, norms consolidating the environmental responsibility concept, the forms of damages reparation and methods for preventing violations. 
The fifth part is the mechanism of international legal protection of the environment including principles, treaties and conventions, internationally protected objects, international organizations and international conferences ${ }^{17}$.

Ignoring the division of the environmental law into the General and Special parts, he, nevertheless, considered the economic mechanism as a subinstitution of the legal institution of the "mechanism of the environmental law".

We believe that the norms related to the mechanism of economic regulation of environmental protection and nature resource management have the status of an independent legal institution that has a right to exist.

The norms of economic regulation of environmental protection and nature resource management should be included in the Special part of the environmental law.

\section{Conclusion}

Summing up the results of our study, we have come to the following conclusions:

At the present stage of development of the environmental law and legislation in the Republic of Kazakhstan, the norms related to the economic regulation of environmental protection and nature resource management represent an independent legal institution, which may be called the "mechanism of economic regulation of environmental protection and nature resource management". This legal institution definitely belongs to the General part of the environmental law that comes out of its significance for the main institutions of the Special part of the environmental law.

\section{Acknowledgments}

The scientists specializing in environmental protection issues, namely: Doctor of Law, Professor of the Gumilyov Eurasian University Anara Abaikhanovna Mukasheva, Doctor of Law, Professor of the Gumilyov Eurasian University Zhumash Khazhimbaevich Kossanov rendered a great assistance in preparation of this article.

\section{References}

1. Neresiants VS. Obshchaia teoriia prava i gosudarstva [The
General Theory of Law and State]. Moscow. 2001; 552 [in Russian].

2. Sapargaliiev GS. Konstitutsionnoe pravo Respubliki Kazakhstan [Constitutional Law of the Republic of Kazahstan]. Almaty. 1998; 336 [in Russian].

3. Pigolkin AS. Obshchaia teoriia prava [General Theory of Law]. Moscow. 2000; 159 [in Russian].

4. Alekseev SS. Teoriia gosudarstva i prava [The Theory of State and Law]. Moscow. 1985; 480 [in Russian].

5. Bulgakov DA. Teoriia gosudarstva i prava: Uchebno-metodicheskoe posobie [The Theory of State and Law: Study guide]. Almaty; 1999 [in Russian].

6. Gavrilova Iu A. Pravovoe regulirovanie okhrany i ispolzovaniia transgranichnykh prirodnykh ob"ektov (na primere Respubliki Kazakhstan) [Legal Regulation of Protection and Use of Transboundary Natural Objects (Through the Example of the Republic of Kazakhstan)]. Almaty. 2007; 138 [in Russian].

7. Petrova TV. Problemy pravovogo obespecheniia ekonomicheskogo mekhanizma okhrany okruzhaiushchei sredy [Problems of the legal support of the economic mechanism of environmental protection]. [ $\mathrm{PhD}$ Thesis]. Moscow. 2000; 47 [in Russian].

8. Lazarev VV. Obshchaia teoriia prava i gosudarstva [The General Theory of Law and State]. Moscow. 1996; 432 [in Russian].

9. Kulteleev ST. Ekologicheskoe pravo Respubliki Kazakhstan [Environmental Law of the Republic of Kazakhstan]. Almaty. 2003; 328 [in Russian].

10. Baideldinov DL. Ekologicheskoe pravo Respubliki Kazakhstan [Environmental Law of the Republic of Kazakhstan]. Almaty; 2004 [in Russian].

11. Bystrov GE. Ekologicheskoe pravo [Environmental Law]. Moscow. 2008; 656 [in Russian].

12. Ismailova EIu. Ekologicheskoe pravo [Environmental Law]. Moscow. 2004; 414 [in Russian].

13. Kovaleva IS. Ekologicheskoe pravo. Kurs Lektsii [Environmental Law. Lecture course]. Moscow. 2009; 144 [in Russian].

14. Yerofeev BV. Ekologicheskoe pravo [Environmental Law]. Moscow. 2006; 414 [in Russian].

15. Bekisheva SD. Ekologicheskoe pravo Respubliki Kazakhstan [Environmental Law of the Republic of Kazakhstan]. Karaganda; 2009. [in Russian].

16. Dubovik OL. Ekologicheskoe pravo [Environmental Law]. Moscow; 2005 [in Russian].

17. Petrov VV. Ekologicheskoe pravo Rossii [Environmental Law of Russia]. Moscow; 1995 [in Russian]. 